\title{
Building Students' Interest in Learning During a Pandemic Through a Program for Implementing Educational Policies During an Emergency Period for the Spread of Covid-19
}

\author{
Nur Asihkha \\ SDN Ketanggungan 07 \\ nurasihkha@gmail.com
}

\section{Article History}

received $3 / 12 / 2020$

\begin{abstract}
Building student interest in learning is one way so that learning objectives can be achieved. Students who have a high interest in learning will make it easier to understand the learning material. Several programs that can increase the interest of students during the pandemic include 1) Interactive and Non-Interactive Online Learning 2) Life Skills Education 3) Learning in accordance with Student Interests and Conditions 4) Qualitative Assignment Assessment. Can be applied through entertainment methods, creative applications and lesson plans that involve students. With the involvement of teachers in the student learning process will realize the learning objectives to be achieved.
\end{abstract}

Keywords: interest in learning, students, pandemic

\begin{abstract}
Abstrak
Membangun minat belajar peserta didik adalah salah satu cara agar tujuan pembelajaran dapat tercapai. Peserta didik yang memiliki minat belajar yang tinggi akan memudahkan dalam memahami materi pembelajaran. Beberapa program yang dapat meningkatkan minat peserta didik di masa pandemi diantaranya 1) Pembelajaran Daring Interaktif dan Non Interaktif 2) Pendidikan Kecakapan Hidup 3) Pembelajaran Sesuai dengan Minat dan Kondisi Siswa 4) Penilaian Tugas Secara Kualitatif. Dapat diaplikasikan melalui metode hibur, aplikasi kreatif dan rencana pembelajaran yang melibatkan peserta didik. Dengan keterlibatan guru dalam proses belajar siswa akan mewujudkan tujuan pembelajaran yang akan dicapai.
\end{abstract}

Kata kunci: minat belajar, peserta didik, pandemi 


\section{PENDAHULUAN}

Belajar adalah suatu aktivitas yang membutuhkan kesiapan subjek yang mengalaminya. Subjek tersebut adalah peserta didik. Adanya kesiapan peserta didik, akan menumbuhkan minat dalam belajar. Minat belajar adalah salah satu faktor yang sangat penting untuk mewujudkan keberhasilan belajar, minat muncul dari dalam diri siswa itu sendiri. Faktor dari luar minat belajar yaitu bagaimana cara guru tersebut mengajar. Peran guru sangat penting untuk menumbuhkan minat belajar siswa salah satunya dengan cara mengajar yang menyenangkan, dan memberikan motivasi (Riamin, 2016).

Membangun minat peserta didik bukanlah hal yang mudah. Apalagi di masa pandemi sekarang ini, karena peserta didik tidak bisa bertatap muka langsung dengan guru. Dengan adanya virus COVID-19 ini membuat proses pembelajaran menjadi berubah dari yang tatap muka menjadi pembelajaran jarak jauh, tetapi dalam keadaan seperti ini guru masih tetap harus melaksanakan kewajibannya sebagai pengajar, dimana guru harus memastikan peserta didik dapat memperoleh informasi/imu pengetahuan (Aulia, 2020). Hal ini menjadi tantangan guru dalam menyiapkan pembelajaran jarak jauh yang menarik dan menyenangkan. Guru perlu mengetahui karakteristik peserta didik. Dengan mengenali karakter dan latar belakang peserta didik, guru dapat membuat rencana pembelajaran yang dapat menumbuhkan minat belajar peserta didik.

Masa pandemi membuat peserta didik lebih banyak menghabiskan waktunya dengan gadget. Guru harus bisa memanfaatkan aktivitas anak dengan gadget melalui aktivitas belajar online atau daring. Menurut Sanjaya (2009:146) Guru memberikan fasilitas atau kemudahan-kemudahan dalam proses belajar-mengajar, dengan menciptakan suasana kegiatan belajar yang sedemikian rupa, serasi dengan perkembangan siswa, membuat interaksi dalam pembelajaran berlangsung efektif.

Suryabrata (1997:10) mengatakan "kalau seorang tidak berminat untuk mempelajari sesuatu, tidak dapat diharapkan bahwa dia akan berhasil dalam proses belajarnya, dan begitu pula sebaliknya". Seiring berkembangnya teknologi informasi dan komunikasi sekarang ini, menjadi salah satu alasan terbesar anak mengalami malas belajar. Anak zaman sekarang lebih senang dengan gadgetnya. Penggunaan gadget yang salah sangat disayangkan, karena tidak semestinya gadget hanya digunakan untuk bermain game dan berselancar di media social saja. Hal ini menjadi salah satu penyebab rendahnya minat belajar peserta didik.

Kompas.com psikolog Meriyati M.Psi, Psi dalam diskusi daring bertajuk Kesehatan Mental Anak dan Remaja di masa Pandemi covid 19, Selasa (29/6/2021). Mengatakan bahwa pengaruh kesehatan mental yang sangat berpotensi akibat penggunaan gawai dan internet yang berlebihan, adalah kecanduan (adiksi) terhadap internet dan gadget. Seperti kecanduan games, internet, sosial media dan juga online shopping. Jika hal ini tidak segera disadari dan dibenahi oleh orang tuanya, maka kecanduan-kecanduan tersebut bisa merugikan anak-anak dan orang lain.

Contohnya seperti kasus seorang remaja (kelas 2 SMP) asal Sidoarjo, Jawa Timur yang rela mencuri dan membakar rumah tetangganya akibat kecandua game online. la membakar rumah tetanggnya lantaran tidak mendapatkan uang untuk isi ulang atau top up game online, pada 8 Mei 2021 lalu. Tidak hanya itu, akibat game online ini juga, seorang remaja perempuan asal Jambi nekat kabur dari rumah dan terlantar di bandara Soekarno-Hatta, karena ingin bertemu dengan pria sekaligus lawan mainnya di sebuah game online. Meriyati menegaskan, internet dan gawai itu tidak akan menjadi masalah dan tidak akan merugikan orang lain, jika tidak digunakan berlebihan.

Pendidikan sesungguhnya mengarah kepada pembentukan karakter sebagaimana tertuang dalam UU No thn 2003 Bab II Pasal 3 bahwa fungsi dan tujuan pendidikan nasional yaitu: "Pendidikan Nasional berfungsi mengembangkan kemampuan dan membentuk watak serta peradaban bangsayang bermartabat, 
bertujuan untuk berkembangnya potensi peserta didik agar menjadi manusia yang beriman dan bertakwa kepada Tuhan Yang Maha Esa, berakhlak mulia, sehat, berilmu, sehat, kreatif, mandiri, dan menjadi warga negara yang demokratis serta bertanggungjawab". Oleh karena itu, selain ilmu pengetahuan guru harus berperan penting dalam pembentukan karakter anak sehingga menjadi manusia yang berkarakter.

Orang tua dan guru sama-sama bersinergi dalam membentuk karakter anak, sehingga perilaku yang menyimpang yang dilakukan oleh peserta didik dapat dihentikan. Menurut (Sutrisno, 2018) Peran orangtua dan satuan pendidikan juga selalu membatasi penggunaan media digital dengan membuatkan jadwal atau buku harian media dan pendampingan terhadap generasi digital, hadirkan parental control, buat kesepakatan untuk acara televisi yang boleh ditonton dan pastikan acara tersebut memang diperuntukan untuk anak-anak. Berdasarkan kasus-kasus di atas menunjukkan bahwa rendahnya minat belajar peserta didik dipengaruhi oleh gadget. Apalagi di masa pandemi yang menuntut anak untuk menggunakan gadget sebagai fasilitas utama pelaksanaan pembelajaran daring.

\section{HASIL DAN PEMBAHASAN}

Minat merupakan faktor yang sangat penting untuk menunjang kegiatan belajar siswa. Kenyataan ini juga diperkuat oleh pendapat Sardiman (2012:95) yang menyatakan bahwa proses belajar itu akan berjalan lancar kalau disertai dengan minat. Begitu juga menurut William James dalam Usman (2008:27), bahwa minat belajar merupakan faktor utama yang menentukan derajat keaktifan belajar siswa. Jadi, dapat ditegaskan bahwa faktor minat ini merupakan faktor yang berpengaruh secara signifikan terhadap keberhasilan belajar.

Sebagai upaya menegakkan kegiatan belajar mengajar yang lebih menyenangkan, pemerintah melalui Kemendikbud menerapkan beberapa program yang didasarkan pada Surat Edaran No 4 tahun 2020. Melalui surat edaran ini Kemendikbud menetapkan beberapa program pembelajaran di masa pandemi, antara lain:

\section{Pembelajaran Daring Interaktif dan Non Interaktif}

Esensi dari pembelajaran daring adalah bagaimana proses belajar tetap berlangsung selama di rumah. Bukan memindahkan sekolah ke rumah, tetapi guru perlu memilih materi-materi penting yang perlu dilakukan anak-anak di rumah. Faktor infrastruktur memang mempengaruhi proses belajar daring, tetapi bagaimana guru dapat melaksanakan target kurikulum bisa tetap tercapai.

\section{Pendidikan Kecakapan Hidup}

Minat adalah bagaimana seseorang bisa melakukan sesuatu dengan kondisi yang lebih menyenangkan. Sama halnya dalam belajar, perlu ditawarkan hal-hal yang menyenangkan bagi siswa agar lebih enjoy dalam menjalani Kegiatan Belajar mengajar (KBM). Salah satu caranya adalah dengan pendidikan kecakapan hidup yang lebih aplikatif, implementatif, dan kontekstual dengan kondisi sekarang. Misalnya pembelajaran tentang bagaimana cara menghindari virus covid-19, bagaimana menjalankan protokol kesehatan sehari-hari.

\section{Pembelajaran Sesuai dengan Minat dan Kondisi Siswa}

Walaupun dilakukan secara daring, proses belajar mengajar juga tetap harus mengacu pada minat dan kondisi siswa. Tidak bisa disamakan bagaimana fasilitas dan akses belajar siswa di setiap daerah. Dalam hal ini pihak guru sangat penting bersikap bijak menyesuaikan dengan kondisi yang ada tanpa mengabaikan target kurikulum.

\section{Penilaian Tugas Secara Kualitatif}

Dalam penilaian tugas yang diberikan kepada siswa hendaknya guru tidak melakukan penilaian seperti yang biasa dilakukan di sekolah. Penilaian cukup dilakukan secara kualitatif yang sifatnya lebih memberikan motivasi kepada siswa. 


\section{Cara Kreatif Meningkatkan Minat Belajar Siswa di Era Pandemi}

Faktor yang mempengaruhi minat belajar siswa menurun di musim pandemi selain karena alasan fasilitas yang tidak memadai, salah satunya adalah minimnya keterlibatan guru dalam proses KBM. Bertemu hanya melalui layar zoom meeting, google meet, whatsapp atau platform digital lainnya menyebabkan siswa kurang merasakan keterlibatan guru dalam proses KBM yang dijalani. Oleh karena itu, perlu dilakukan beberapa cara kreatif untuk mengatasinya:

\section{1) Metode Hibur}

Dalam pembelajaran bahasa Indonesia dikenal sebuah metode bernama metode hibur yang dapat membantu meningkatkan rasa suka, senang dan minat yang lebih pada suatu materi. Sebagai contoh misalnya para siswa diminta menonton, membaca novel, menikmati tayangan drama dan sebagainya untuk mendapatkan informasi pembelajaran sesuai dengan materi yang diujikan. Di musim pandemi ini, metode hibur ini sangat sesuai diterapkan untuk KBM yang lebih menyenangkan. Guru tidak stres dengan persiapan tugas dan siswa pun tidak bosan dan jenuh karena metode penugasan yang sifatnya menyenangkan dan menghibur.

\section{2) Aplikasi Kreatif}

Siapa dan bagaimana kondisi murid atau siswa yang diajar oleh guru? Hal ini sangat penting diketahui sebelum menerapkan metode kreatif yang menyenangkan. Jika memiliki siswa usia SLTP atau SLTA dengan penguasaan teknologi yang baik, maka guru bisa menggunakan teknik pembelajaran menggunakan berbagai aplikasi teknologi yang kreatif dan menarik. Sebagai contoh penggunaan aplikasi TikTok yang saat ini lebih banyak disukai kalangan muda. Aplikasi ini bisa dimanfaatkan untuk perangkat belajar yang lebih kreatif dan menyenangkan bagi siswa.

Ada saatnya siswa jenuh di depan zoom meeting, google meet dan sejenisnya. Cobalah beralih ke aplikasi kekinian yang lebih digemari dan menampilkan fitur-fitur kreatif. Hal ini sehubungan dengan karakter peserta didik di abad 21 yang lebih tertarik dengan internet.

\section{3) Membuat Rencana Pembelajaran yang Melibatkan Siswa}

Selama ini seringkali guru membuat rencana pembelajaran dilakukan sesuai dengan kebutuhan kurikulum dan tanpa melibatkan siswa. Kondisi pandemi saat ini di mana minat belajar siswa cenderung menurun dibutuhkan hal-hal yang sifat aspiratif dari keinginan siswa. Libatkan rencana pembelajaran dengan keinginan dan kondisi siswa sehingga lebih bisa diterima dan dijalankan dengan kondisi yang menyenangkan. Sehebat apapun rencana pembelajaran yang dibuat di musim pandemi, jika siswa tidak tertarik menjalankannya maka akan sulit bagi guru menjalankan proses KBM yang maksimal.

\section{SIMPULAN}

Minat belajar peserta didik dapat ditumbuhkan melalui pembelajaran yang menarik, perencanaan yang matang dan usaha-usaha guru dalam praktik pembelajaran baik secara langsung maupun tidak langsung (daring). Usaha-usaha tersebut dapat diwujudkan melalui program yang dapat meningkatkan minat peserta didik di masa pandemi diantaranya 1) Pembelajaran Daring Interaktif dan Non Interaktif 2) Pendidikan Kecakapan Hidup 3) Pembelajaran Sesuai dengan Minat dan Kondisi Siswa 4) Penilaian Tugas Secara Kualitatif. Dapat diaplikasikan melalui metode hibur, aplikasi kreatif dan rencana pembelajaran yang melibatkan peserta didik. Dengan keterlibatan guru secara penuh dalam proses belajar siswa akan mewujudkan tujuan pembelajaran yang akan dicapai.

DAFTAR PUSTAKA

Aulia, S. (2020). Pembelajaran Daring Pada Masa Pandemi. 20 Juli. https://www.suara.com/yoursay/2020/07/20/175556/pembelajaran-daring-padamasapandemi 
Sutrisno, F. \&. (2018). Pendampingan Orang Tua Dalam Menghadapi Era Digital Bagi Siswa Sekolah Dasar Setiabudi Kecamatan Karet Jakarta Selatan. Jurnal Pemberdayaan Sekolah Dasar, 1(1), 19-22.

Surat Edaran Mendikbud No 4 Tahun 2020 Tentang Pelaksanaan Kebijakan Pendidikan Dalam Masa Darurat Penyebaran Corona Virus Disease (Covid-19) Retrieved from https://pintek.id/blog/minat-belajar-siswa/

Riamin. (2016). Menumbuhkan Minat Belajar Siswa dalam Pembelajaran. 14 April. https://www.kompasiana.com/riamin/570ec6323697738d1a3e38b6/menumbuhk an-minatbelajar-siswa-dalam-pembelajaran

Sanjaya, Wina. 2009, Strategi Pembelajaran Berorientasi Standar Proses Pendidikan. Jakarta: Kencana

Sardiman, A.M. 2012. Interaksi dan Motivasi Belajar Mengajar. Jakarta: Raja Grafindo Persada

Suryabrata. (1997). Proses Belajar Mengajar Di Sekolah. Jakarta: Rineka Cipta.

Undang-undang SISDIKNAS (Sistem Pendidikan Nasional) (UU RI No.20 Th.2003). 